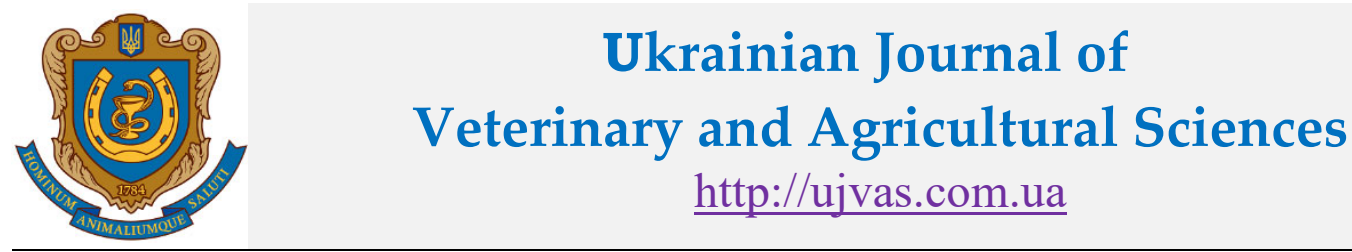

Stepan Gzhytskyi National University of Veterinary Medicine and Biotechnologies Lviv original article $\mid$ UDC 619:616-08:619:616.99:636.2 $\mid$ doi: 10.32718/ujvas4-1.03 $\quad$ Number 1

\title{
Protein-synthesizing function of the liver of cows at experimental fasciolosis
}

\author{
D. V. Frejuk, V. V. Stybel \\ Stepan Gzhytskyi National University of Veterinary Medicine and Biotechnologies, Pekarska Str., 50, Lviv, 79010, Ukraine
}

\begin{abstract}
Article info
Received 10.12 .2020

Received in revised form 11.01.2021

Accepted 12.01.2021

Correspondence author

Dmytro Frejuk

Tel.: +38-097-448-24-11

E-mail:frejukdima@gmail.com

2021 Frejuk D., Stybel V. This is an open-access article distributed under the terms of the Creative Commons Attribution License, which permits unrestricted use, distribution, and reproduction in any medium, provided the original author and source are credited.

\section{(cc) BY}

Abstract

Cattle fasciolosis is quite widespread in the world, including in Ukraine. Animal blood proteins, being in close functional connection with proteins of various tissues, reflect the changes that occur in the tissues and organs of the body during disorders of their metabolic processes caused by pathological factors. The aim of the study was to investigate the level of total protein and its fractions in the blood of cows in experimental fasciolosis. 12 cows of 4-5 years of age, black-spotted breed, were selected for experiment, out of which 2 groups were formed, six animals in each. Animals in the control group were clinically healthy. Animals of the experimental group were experimentally infected with adolescents. During the research, the rules of compulsory experiments were followed selection and keeping of analogue animals in groups. The cows' diet was balanced in terms of nutrients and minerals. In the study of protein-sensitizing function of the liver of cows, it was found that during fasciolosis invasion, the content of total protein decreased by $13.8 \%$. These changes were due to a decrease in albumin and an increase in globulins. Thus, in fasciological invasion of cows, the level of albumin in the serum decreased by $24.4 \%$, and the level of globulins increased by $7.9 \%$. The value of the albumin / globulin ratio in the blood of infested cows with the causative agent of fasciolosis is quite indicative. It was found that the albumin-globulin ratio in the blood of cows of the experimental group was probably lower compared to the control group of animals. This value of the coefficient, of course, indicates the suppression of protein-synthesizing function of the liver in these periods of research. In the future it is planned to investigate the functional state of the liver of cows with experimental fasciolosis.
\end{abstract}

Contents

1. Introduction

2. Materials and methods

3. Results and discussion ........ 13

4. Conclusions $\ldots \ldots \ldots \ldots \ldots \ldots, 14$

References ........................ 14

Key words: parasitology, ruminants, fasciolosis, liver, proteins, albumins, globulins.

\section{Citation:}

Frejuk, D. V., Stybel, V. V. (2021). Protein-synthesizing function of the liver of cows at experimental fasciolosis. Ukrainian Journal of Veterinary and Agricultural Sciences, 4(1), 12-15.

\section{Introduction}

Fasciolosis is one of the most dangerous helminthiasis, which causes significant economic damage to farms. Fasciolosis of cattle is quite widespread in the world, including in Ukraine (Kulyaba et al., 2016; 2017; 2019; Chernushkin et al., 2020). It is known that the disease is caused by two pathogens - common (liver) and giant fasciola, which belong to the same genus (Fasciola), but differ in morphology (Mooney et al., 2009; Ashrafi, 2015; Aly et al., 2020).

The adult stage of helminths is localized in the liver and gallbladder, while the larval stage is found in the lungs. (Mitchell, 2002; Moghaddam et al., 2004). While parasitizing in the body of the host fascioles secrete products of life and toxic products that damage the biological membranes of cells, inhibit cellular mechanisms of energy supply, the activity of membrane-dependent enzymes and disrupt the transport of substances across membranes (Macs et al., 1988; Mas-Coma et al., 2005; Matanović et al., 2007; Vázquez et al., 2016).

In the liver as the largest digestive gland of the body of cows are concentrated the most important physiological and biochemical processes necessary to maintain homeostasis of animals. An important indicator of protein-synthesizing function of the liver is to determine the level of total protein and its fractions in the serum of infected animals (Lavryshyn \& Gutyj, 2019). It reflects the changes that occur in the body of cows in various pathological conditions (Said et al., 2020; Slivinska et al., 2020), including experimental fasciolosis. Animal blood proteins, being in close functional connection with proteins of various tissues, reflect the changes that occur in the tissues and organs of the body during disorders of their metabolic processes caused by pathological factors. (Gutyj et al., 2017; 2019).

The aim of the study was to investigate the level of total protein and its fractions in the blood of cows in experimental fasciolosis.

\section{Materials and methods}

12 cows of 4-5 years of age, black-spotted breed, were selected for experiment, out of which 2 groups were formed, six animals in each. Control group (C) animals were clinically healthy. Animals of experimental group (R) were ex- 
perimentally infected with adolescents. During the research, the rules of compulsory experiments were followed - selection and keeping of analogue animals in groups. The cows' diet was balanced in terms of nutrients and minerals.

All animal manipulations were performed in accordance with the European Convention for the Protection of Vertebrate Animals Used for Experimental and Scientific Purposes (Official Journal of the European Union L276/33, 2010).

Blood for analysis was taken from the jugular vein before infection and on the 5th, 10th, 15th, 20th, 25th and 30th day of the experiment.

The concentration of protein and its fractions was studied according to the method (Vlizlo, 2012).

The analysis of research results was performed using the software package Statistica 6.0. The probability of differences was assessed by Student's t-test. The results were considered plausible at $\mathrm{P} \leq 0.05$.

\section{Results and discussion}

According to studies, the clinical manifestation of fasciological invasion in cows of the experimental group decreases the level of total protein, where respectively on the 10th day of the experiment it decreased by $4.7 \%$, and on the 15 th day of the experiment - by $7.4 \%$ relative to the control group of animals (Table 1).

\section{Table 1}

The level of total protein in the blood of cows with experimental fasciolosis $(M \pm m, n=6)$

\begin{tabular}{ccc}
\hline \multirow{2}{*}{$\begin{array}{c}\text { Blood test time } \\
\text { (days) }\end{array}$} & \multicolumn{2}{c}{ Total protein, g/l } \\
\cline { 2 - 3 } & \multicolumn{2}{c}{ Croups of animals } \\
\cline { 2 - 3 } Before infection & $72.6 \pm 1.1$ & Research \\
5 day & $72.4 \pm 1.0 \pm 1.2$ \\
10 day & $72.8 \pm 1.2$ & $71.2 \pm 1.3$ \\
15 day & $73.0 \pm 1.1$ & $69.4 \pm 1.2$ \\
20 day & $72.7 \pm 1.1$ & $65.4 \pm 1.3^{*}$ \\
25 day & $72.5 \pm 1.3$ & $62.5 \pm 1.0^{* *}$ \\
30 day & $72.7 \pm 1.1$ & $63.1 \pm 1.0^{*}$ \\
\hline
\end{tabular}

On the 20th day of the experiment, the level of total protein in the blood of the experimental group of cows continued to decrease and accordingly amounted to $65.4 \pm 1.3 \mathrm{~g} / \mathrm{l}$, while in the control group of cows it was $72.7 \pm 1.1 \mathrm{~g} / \mathrm{l}$. On the 25 th day of the experiment, the level of total protein in the blood of the experimental group of animals was the lowest, where relative to the control group of animals it decreased by $13.8 \%$. On the 30th day of the experiment, the level of total protein in the blood of inoculated cows increased slightly, but compared to the control group remained lower by $13.2 \%$, respectively.

The decrease in total protein in the blood of cows of the experimental group was due to a decrease in albumin levels. The decrease in the plasma of cows of the experimental group of total protein on the background of a decrease in albumin fraction confirms the violation of proteinsynthesizing function of cows' liver in experimental fasciolosis and the development of inflammatory reaction, which is known to be characteristic of cytolytic syndrome. This syndrome occurs as a result of disruption of the structure of liver cells, especially hepatocytes. Sometimes only cell membranes can be damaged, more often - even the cytoplasm, as well as individual cells as a whole.

It was found in the study of albumin levels that on the 15 th day of the experiment, the level of this indicator in the blood of cows of the experimental group decreased by $16.9 \%$ relative to the control group of cows (Table 2). On 20 and 25 days of the experiment, the amount of albumin continued to decrease and was respectively $37.5 \pm 1.0$ and $34.0 \pm 0.8 \mathrm{~g} / \mathrm{l}$. It should be noted that the lowest level of albumin was in the blood of cows of the experimental group on the 25th day of the experiment, where compared with the control group it decreased by $24.4 \%$, respectively.

Table 2

The level of albumin in the blood of cows in experimental fasciolosis $(M \pm m, n=6)$

\begin{tabular}{ccc}
\hline \multirow{2}{*}{$\begin{array}{c}\text { Blood test time } \\
\text { (days) }\end{array}$} & \multicolumn{2}{c}{ Albumins, g/l } \\
\cline { 2 - 3 } & \multicolumn{2}{c}{ Croup of animals } \\
\hline Before infection & $45.3 \pm 1.0$ & Research \\
5 day & $45.0 \pm 1.1$ & $44.1 \pm 1.1$ \\
10 day & $44.9 \pm 1.0$ & $40.6 \pm 1.2^{*}$ \\
15 day & $45.1 \pm 1.2$ & $37.5 \pm 1.0^{* *}$ \\
20 day & $44.9 \pm 1.0$ & $35.8 \pm 0.7^{* *}$ \\
25 day & $45.0 \pm 1.1$ & $34.0 \pm 0.8^{* * *}$ \\
30 day & $45.4 \pm 1.0$ & $34.6 \pm 1.0^{* *}$ \\
\hline
\end{tabular}

It was found on the 30th day of the experiment that the level of albumin in the blood of the experimental group was $34.6 \pm 1.0 \mathrm{~g} / \mathrm{l}$, while in the control group of cows this figure was slightly higher and was $45.4 \pm 1.0 \mathrm{~g} / 1$.

In response to hypoalbuminemia in the blood plasma of infected animals of the experimental group there was a compensatory increase in the content of globulins. Thus, on the 15th day of the experiment in the blood of the experimental group of animals found an increase in the level of globulin fraction by $7.9 \%$ relative to the control group of cows (Table 3 ).

Table 3

The level of globulins in the blood of cows in experimental fasciolosis $(M \pm m, n=6)$

\begin{tabular}{ccc}
\hline \multirow{2}{*}{$\begin{array}{c}\text { Blood test time } \\
\text { (days) }\end{array}$} & \multicolumn{2}{c}{ Globulins, g/l } \\
\cline { 2 - 3 } & \multicolumn{2}{c}{ Group of animals } \\
\cline { 2 - 3 } Before infection & $27.3 \pm 0.7$ & Research \\
5 day & $27.4 \pm 0.6$ & $27.1 \pm 1.0$ \\
10 day & $27.9 \pm 0.7$ & $28.8 \pm 0.6$ \\
15 day & $27.9 \pm 0.8$ & $30.1 \pm 0.8^{*}$ \\
20 day & $27.8 \pm 0.6$ & $29,6 \pm 1.0$ \\
25 day & $27.5 \pm 0.8$ & $28.5 \pm 0.9$ \\
30 day & $27.3 \pm 0.7$ & $28.5 \pm 0.5$ \\
\hline
\end{tabular}

A slight decrease in this indicator was found on the 20th and 25th day of the experiment in the blood of cows of the experimental group compared to the previous day, but it should be noted that the level of globulins in the blood of this group of animals remained high. On the 30th day of the experiment, the level of globulins in the blood of cows of 
the experimental group increased by $4.4 \%$ compared with the control group of animals.

The value of the albumin/globulin ratio in the blood of infested cows with the causative agent of fasciolosis is quite indicative. It was found that the albumin-globulin ratio in the blood of cows of the experimental group was probably lower from 10 days of the experiment. This value of the coefficient, of course, indicates the suppression of proteinsynthesizing function of the liver in these periods of research.

It was found in the blood of infested cows of the experimental group on the 15 th day of the experiment a decrease in this ratio by $22.8 \%$, and on the 20 th day - by $25.3 \%$ relative to the control group. On the 25 th day of the experiment, the lowest $\mathrm{A} / \mathrm{G}$ ratio was found in the blood of cows of the experimental group, which was $1.19 \pm 0.04$, respectively, while in the control group it was $1.64 \pm 0.03$ (Table 2).

\section{Table 4}

Coefficient of $\mathrm{A} / \mathrm{G}$ in the blood of cows with experimental fasciolosis $(M \pm m, n=6)$

\begin{tabular}{|c|c|c|}
\hline \multirow{3}{*}{$\begin{array}{l}\text { Blood test time } \\
\quad \text { (days) }\end{array}$} & \multirow{2}{*}{\multicolumn{2}{|c|}{$\frac{\mathrm{A} / \mathrm{G} \text { ratio }}{\text { Groups of animals }}$}} \\
\hline & & \\
\hline & Control & Research \\
\hline Before infection & $1.66 \pm 0.04$ & $1.66 \pm 0.05$ \\
\hline 5 day & $1.64 \pm 0.05$ & $1.63 \pm 0.02$ \\
\hline 10 day & $1.61 \pm 0.03$ & $1.41 \pm 0.04 *$ \\
\hline 15 day & $1.62 \pm 0.03$ & $1.25 \pm 0.02 * * *$ \\
\hline 20 day & $1.62 \pm 0.04$ & $1.21 \pm 0.06^{* * *}$ \\
\hline 25 day & $1.64 \pm 0.03$ & $1.19 \pm 0.04 * * *$ \\
\hline 30 day & $1.66 \pm 0.05$ & $1.21 \pm 0.02 * * *$ \\
\hline
\end{tabular}

Thus, in cows with the development of experimental fasciolosis inhibits the synthesis of albumin in the liver due to toxic metabolites secreted by fasciols, while the increase in globulin levels in their blood reflects the intensity of inflammatory processes in cows of the experimental group, as indicated by low $\mathrm{A} / \mathrm{G}$ coefficient in infested cows.

\section{Conclusions}

In cows with experimental fasciolosis, a pronounced violation of the protein-synthesizing function of the liver was found, which was manifested by a decrease in the level of total protein and albumin with a simultaneous increase in the level of globulins in their blood.

Prospects for further research. In the future it is planned to investigate the functional state of the liver of cows with experimental fasciolosis.

\section{Conflict of interest}

The authors declare that there is no conflict of interest.

\section{References}

Aly, I. R., Hamad, R. S., Elshall, M., \& Ahmed, M. (2020). Novel expression of Cathepsin B Fasciola gigantica sequence for detection of human fascioliasis in Egypt. International journal of infectious diseases, 101(1), 251. doi: 10.1016/j.ijid.2020.11.091.
Ashrafi, K. (2015). The Status of Human and Animal Fascioliasis in Iran: A Narrative Review Article. Iran J Parasitol, 10(3): 306-328. URL: https://pubmed.ncbi.nlm.nih.gov/26622287.

Chernushkin, B. O., Vlizlo, V.V., Slivinska, L. G., Gutyj, B. V., Shcherbatyy, A. R., Maksymovych, I. A., Leno, M. I., Rusyn, V. I., Lychuk, M. H., Fedorovych, V. L., Lukashchuk, B. O., Zinko, H. O., Prystupa, O. I. (2020). Treatment strategies for sheep with acute yellow athrophy of the liver caused by the fasciolosis. Ukrainian Journal of Ecology, 10(2), 294-301. doi: $10.15421 / 2020100$.

Gutyj, B., Stybel, V., Hariv, I., Maksymovych, I., Buczek, K., Staniec, M., Milczak, A., Bushueva, I., Kulish, S., Shcherbyna, R., \& Samura, T. (2019). Influence Of Amprolinsile And Brovitacoccid On The Protein Synthesizing Function Of The Liver And Enzyme Activity In Turkey Blood Serum During Eimeria Invasion. Research Journal of Pharmaceutical, Biological and Chemical Sciences, 10(2), 723-729.

Gutyj, B., Grymak, Y., Drach, M., Bilyk, O., Matsjuk, O., Magrelo, N., Zmiya, M., \& Katsaraba, O. (2017). The impact of endogenous intoxication on biochemical indicators of blood of pregnant cows. Regulatory Mechanisms in Biosystems, 8(3), 438-443. doi: 10.15421/021768.

Gutyj, B., Khariv, I., Binkevych, V., Binkevych, O., Levkivska, N., Levkivskyj, D., \& Vavrysevich, Y. (2017). Research on acute and chronic toxity of the experimental drug Amprolinsyl. Regulatory Mechanisms in Biosystems, 8(1), 41-45. doi: $10.15421 / 021708$.

Gutyj, B., Ostapiuk, A., Kachmar, N., Stadnytska O., Sobolev O., Binkevych V., Petryshak R., Petryshak O., Kulyaba, O., Naumyuk, A., Nedashkivsky, V., Nedashkivska, N., Magrelo, N., Golodyuk, I., Nazaruk, N., \& Binkevych, O. (2019). The effect of cadmium loading on protein synthesis function and functional state of laying hens' liver. Ukrainian Journal of Ecology, 9(3), 222-226. URL: https://www.ujecology.com/ abstract/the-effect-of-cadmium-loading-on-protein-synthesisfunction-and-functional-state-of-laying-hens-liver-44516.html.

Kulyaba, O. V., Stybel, V. V., \& Gutyj, B. V. (2016). The influence of clozaverm A and catozal on antioxidant status of cows organism for the experimental fasciolosis, sensitized atypical mycobacteria. Scientific Messenger LNUVMBT named after S. Z. Gzhytskyj, 18, 2(66), 96-99. doi: 10.15421/nvlvet6621.

Kulyaba, O., Stybel, V., \& Gutyj, B. (2017). The influence of closaverm a and catosal on indicators of protein synthesizing functions of cows liver by experimental fasciolosis, sentsitized by atypical mycobacteria. Scientific Messenger LNUVMBT named after S.Z. Gzhytskyj, 19(73), 122-125. doi: 10.15421/nvlvet7325.

Kulyaba, O., Stybel, V., Gutyj, B., Turko, I., Peleno, R., Turko, Ya., Golovach, P., Vishchur, V., Prijma, O., Mazur, I., Dutka, V., Todoriuk, V., Golub, O. Dmytriv, O., \& Oseredchuk, R. (2019). Effect of experimental fascioliasis on the protein synthesis function of cow liver. Ukrainian Journal of Ecology, 9(4), 612-615. URL: https://www.ujecology.com/articles/effect-of-experimental -fascioliasis-on-the-protein-synthesis-function-of-cow-liver.pdf.

Lavryshyn, Y. Y., \& Gutyj, B. V. (2019). Protein synthesize function of bulls liver at experimental chronic cadmium toxicity. Scientific Messenger of Lviv National University of Veterinary Medicine and Biotechnologies. Series: Veterinary sciences, 21(94), 92-96. doi: 10.32718/nvlvet9417.

Macs, L., Lauvers, H., Deckers, W., \& Vanparijs, O. (1988). Flukicidal action of closantel against immature and mature Fasciola hepatica in experimentally infected rats and sheep. Res Vet Sci, 44(2), 229-232. doi: 10.1016/S00345288(18)30845-2.

Mas-Coma, S., Bargues, M. D., \& Valero, M. A. (2005). Fascioliasis and other plant-borne trematode zoonoses. International Journal for Parasitology, 35, 1255-1278. doi: 10.1016/j.ijpara.2005.07.010.

Matanović, K., Severin, K., Martinković, F., Šimpraga, M., Janicki, Z., \& Barišić, J. (2007). Hematological and biochemical changes in organically farmed sheep naturally infected with 
Fasciola hepatica. Parasitol Res, 101(6), 1657-1661. doi: 10.1007/s00436-007-0709-2.

Mitchell, G. (2002). Update on fasciolosis in cattle and sheep. In Practice, 24, 378-385. doi: 10.1136/inpract.24.7.378.

Moghaddam, A., Massoud, J., Mahmoodi, M., Mahvi, A. H., Periago, M. V., Artigas, P., Fuentes, M. V., Bargues, M. D., \& Mas-Coma, S. (2004). Human and animal fascioliasis in Mazandaran Province, northern Iran. Parasitol Res, 94(1), 61-69. doi: 10.1007/s00436-004-1169-6.

Mooney, L., Good, B., Hanrahan, J. P., Mulcahy, G., \& de Waal, T. (2009). The comparative efficacy of four anthelmintics against a natural acquired Fasciola hepatica infection in hill sheep flock in the west of Ireland. Veterinary Parasitology, 164(2-4), 201-205. doi: 10.1016/j.vetpar.2009.05.017.

Said, W. S., Stybel, V. V., Gutyj, B. V., Pryima, O. B., \& Mazur, I. Y. (2020). Protein-synthesizing function and functional state of the liver of dogs at experimental toxocariasis. Scientific Mes- senger of Lviv National University of Veterinary Medicine and Biotechnologies. Series: Veterinary sciences, 22(98), 132-137. doi: 10.32718/nvlvet9823.

Slivinska, L. G., Shcherbatyy, A. R., Lukashchuk, B. O., \& Gutyj, B. V. (2020). The state of antioxidant protection system in cows under the influence of heavy metals. Regulatory Mechanisms in Biosystems, 11(2), 237-242. doi:10.15421/022035.

Vázquez, A. A., Lounnas, M., Sánchez, J., Alba, A., Milesi, A., \& Hurtrez-Boussès, S. (2016). Genetic and infective diversity of the liver fluke Fasciola hepatica (Trematoda: Digenea) from Cuba. Journal of Helminthology, 90(6), 719-725. doi: 10.1017/S0022149X15001029.

Vlizlo, V. V. (2012). Laboratorni metody doslidzhen u biologiyi, tvarynnycztvi ta veterynarnij medycyni: dovidnyk. Lviv: Spolom (in Ukrainian). 